DOI: https://doi.org/10.32839/2304-5809/2021-11-99-85

удК 330.8

Можелянська А.В., Новоселець А.I.

Харківський національний аграрний університет імені В.В. Докучаева

\title{
ПРОБЛЕМАТИКА ІСТИНИ У ДОСЛІДЖЕННЯХ ЕКОНОМІКИ АГРАРНОГО СЕКТОРУ
}

Анотація. Досліджено основні теоретичні питання формування істини в економіці аграрного сектора. Визначено основні напрями розвитку і формування істини економічних досліджень аграрного сектору, які визначають структуру формування мети досліджень та впровадження їх результатів. В процесі проведення досліджень вчених-економістів щодо походження і природи наукових знань та наукового методу, встановлено, що останні складалися під впливом загальнонаукових методологічних стандартів, що відображали досвід провідних науковців галузі. Економічна наука потребує професіоналізації методології, що започаткуе істотні зміни у взаємовідносинах між методологами і фрахівцями у агарному секторі та забезпечить істину наукових пізнань на рівні стратегічних дій держави.

Ключові слова: економіка, аграрний сектор, дослідження, проблематика, істинна знання.

Mozhelyanska Anna, Novoselets Artem Kharkiv National Agrarian University named after V.V. Dokuchaiev

\section{THE PROBLEMATICS OF TRUTH IN AGRICULTURAL ECONOMICS RESEARCH}

Summary. The main theoretical issues of truth formation in the economy of the agricultural sector are studied. The main directions of development and formation of the truth of economic research of the agricultural sector are determined, which determine the structure of the formation of the purpose of research and implementation of their results. The concept of economy arose only after the economy itself as an objective phenomenon emerged from the inseparable primarily social fabric in the autonomous subsystem of society, which occurred in the process of forming market economies in modern times. The economy of the agricultural sector is an explanation of economic facts, a better understanding and prediction of economic and political events and the basis for finding new vectors for the development of the agricultural sector. In the process of conducting research by economists on the origin and nature of scientific knowledge and scientific method, it was found that the latter were formed under the influence of general scientific methodological standards that reflect the experience of leading scientists in the field. Scientists of economic research in the agricultural sector should use the experience of science and learn to determine the extent and relativity of holistic truth, strict conditions, prerequisites and boundaries in which economic-universal knowledge corresponds to a particular area of a complex object. We also consider it necessary to note that economics requires the professionalization of methodology, which will initiate significant changes in the relationship between methodologists and specialists in the agar sector and ensure the truth of scientific knowledge at the level of strategic action. Research of the main directions of development and formation of the truth of economic researches of agricultural sector is an actual direction that will provide clearer formation of the purpose of researches and introduction of their results. Economics requires the professionalization of methodology, which will initiate significant changes in the relationship between methodologists and specialists in the agar sector and ensure the truth of scientific knowledge at the level of strategic actions of the state.

Keywords: economy, agricultural sector, research, problems, true knowledge.

$\Pi$ остановка проблеми. Сучасна постнеокласична наука значно відрізняеться від своїх «попередників» - давньосхідної, античної, середньовічної, класичної та некласної - неординарністю та складністю об'єкта та суб'єкта, глобальним та універсальним характером, яскраво вираженою соціальністю та колективністю, глибиною диференціації, мережевими взаємодіями, чітко вираженим конструктивізмом, технологізмом, прагматизмом до вузького практищизма. Випереджаючий розвиток та домінування прикладних наукових розробок над фондаментальними дослідженнями дають підставу науковцям констатувати розвиток абстрактної істини нових знань, а ефрективність та рентабельність стають ключовими критеріями оцінки адекватності та цінності проведеного наукового дослідження [6]. Не менш значущим є прогресуючий «новий економічний імперіалізм» - активний розвиток та входження економічної науки у предметні галузі інших наук, у яких проблематика істини практично не актуалізована.

Структура економічного знання 3 погляду його змісту визначається диференціацією науково- дослідних програм та сформованих на їх основі наукових напрямів, шкіл та традищій. В основі кожної науково-дослідної програми є ядро: набір базових установок, що визначають економічну реальність, або онтологію. Своє відображення ці установки знаходять у науковій термінології та тематиці наукових досліджень економіки аграрного сектору, соціальних нормах наукової роботи у цій галузі [5]. Одним із головних напрямів розвитку економіки аграрного сектору як науки $є$ розширення спектру науково-дослідних програм. Таким чином, механізм генерування нових знань охоплюе широке коло традищійних проблем епістемології та методології у вузькому значенні. Погляди вчених-економістів на походження та природу наукових знань та наукового методу складалися під впливом загальнонаукових методологічних стандартів, що відображали досвід провідних науковців галузі [3; 7]. 3 еволюцією часу у ролі еталонів галузі виступали математика та астрономія, теоретична фрізика та еволюційна біологія.

Отже, однозначної відповіді щодо істини у наукових пошуках в галузі економіки аграр- 
ного сектору не існує без нової ідентифрікації самої істини, яка не може залишатися незмінною в умовах ускладнення та універсалізації науки та їі об'єкта. Тому, дослідження основних напрямів розвитку і формування істини економічних досліджень аграрного сектору є актуальним напрямом, що забезпечить більш чітке фрормування мети досліджень та впровадження їx peзультатів.

Аналіз останніх досліджень і публікацій. 3 часом актуальність питання істини економічних досліджень зростає. У дослідження таких вчених-науковців, як: О. Ананьина, О. Антоновского, М. Блауга, С. Лебедева, Т. Лоусона, В. Тарасевич та ін. [1-7], чітко відображена проблематика істини у економічних дослідженнях. Проте існуе необхідність досліджень відповідно до вимог часу із врахуванням новацій у сфрері проведення економічних досліджень. Також необхідним $є$ врахування специфіки аграрного сектору у контексті економічних досліджень.

Виділення не вирішених раніше частин загальної проблеми. Розглядаються основні передумови формування істину у економічних дослідженнях агарного сектору з врахуванням змін часу.

Мета статті. Головною метою ціеї роботи є обгрунтування теоретичних аспектів формування істини у дослідженнях економіки агарного сектору із врахуванням сучасних модернізаційних процесів наукової діяльності.

Виклад основного матеріалу. Досліджено, що фрілософии і теоретики у різних сфрерах дослідження стверджують, що гуманітарні науки насправді просто неможливі. Згідно даної позиціï, існуючі гуманітарні дослідження насправді не продукують знання, не набувають істини про те, що має місце насправді. В обтрунтування цієї тези наводяться такі аргументи. По-перше, продукт діяльності дослідників людини зазвичай ціннісно і ідеологічно навантажений, оскільки цінності різних груп дослідників різні, неможливо отримати загальноприйняте, об'єктивне знання. Так, історики зазвичай виділяють різні фракти, виходячи зі своїх ідеологічних пристрастей, по-різному їх пояснюють та оцінюють. Прийти до єдиної думки щодо того, що насправді відбувалося у минулому, вважають прихильники цього погляду на гуманітарну науку, неможливо [2; 4; 8]. По-друге, у разі експериментів 3 людиною, які проводять, наприклад, психологи в результаті демонструє такі свої особливості, які не існують поза експериментом. У разі вивчення громадської думки самі питання соціолога створюють у опитуваного стан, якого не існувало до опитування. По-трете, на основі справжнього знання можна визначити майбутне, як це має місце в природничих науках.

Функціональна структура наукового економічного знання включає: теоретичне знання; емпіричне знання (сукупність фрактів, що отримали тлумачення в рамках відповідної теорії та складових їі емпіричний базис); онтологічне знання, що складається з узагальнених уявлень про предметну галузь, узгоджених 3 ширшими світоглядними установками; інструментальне знання та навички за технологією дослідницької роботи; інструментальне знання та навички прикладного характеру, що $є$ основою мистецтва економіки (включаючи значний корпус досвідченого знання).

Економіка аграрного сектору - це систематизоване знання про стійкі, повторювані зв'язки в економічних явищах i процесах аграрного сектору, їх структурні характеристики, закономірності фонкціонування і тенденції розвитку. Економіка аграрного сектору є пояснення економічних фрактів, кращого розуміння і передбачення господарсько-політичних подій та основою пошуку нових векторів розвитку аграрного сектору. Сукупність теорій різного рівня становить економічну теорію економіки у сенсі слова [6-7].

Економічні теорії будуються з відповідних понять - економічних категорій і включають, як правило, такі елементи: вихідні посилки (аксіоми, постулати); теоретичні моделі; теоретичні твердження, чи висновки (закони, теореми, гіпотези, передбачення тощо); свідчення правдоподібності (істинності) теоретичних висновків чи умови перевірки гіпотез. Економічні категорії - це абстрактні теоретичні поняття, що позначають основні елементи економічної реальності. Зміст категорій залежить від теоретичного контексту: категорії, які виражаються однаковими термінами, але використовуються різними науковими школами, часто мають різний зміст (напр., «капітал» у теоріях А. Сміта, К. Маркса, Є. Бем-Баверка та Д. Б. Кларка) [3; 5; 8].

На відміну від фрілософрів, вчені спочатку не повною мірою усвідомили важливість кантіанської гносеологічної револющії. У дослідженні Кантом залежність знань від апріорних форм чуттевості та розуму, в горезвісній «речі у собі» вони побачили лише відмову від пошуку істини. Тим часом, у дослідженні Канта закладено набагато глибший зміст: у пошуку істини слід брати до уваги і згоду мислення із самим собою, і відношення знання не тільки до об'єкта вивчення, апріорних форм чуттевості та розуму, але й до інших френоменів буття і мислення [4]. Провідні вчені-економісти, з одного боку, продовжували кореспондентський підхід до істини, про що свідчать фондаментальні вчення А. Сміта і Д. Рікардо, а 3 іншого - у відомій «суперечці про метод» продемонстрували можливості виходу за його межі [5]. У суперечщі було відмічено, дві значущі для майбутнього економічної науки аграрного сектору проблеми: про різні види істинного економічного знання або про істину різних видів економічного знання; про відношення знання до результатів його практичного застосування [8].

У пошуках інструментарію економічних досліджень аграрного сектору, адекватного рівню складності об'єкта пізнання, вчені-економісти активізують редлексію над відношенням знання до засобів і операцій наукової діяльності. Кореспондентська концепція істини переміщуеться зі сцени за куліси [8]. Судячи з темпів i характеру експансії математики в чисту неокласичну теорію, важко позбутися думки, що гострота інтересу до отримання істинного знання за допомогою математичних методів обернено пропорційна гостроті вражень від запаморочливих економіко-математичних конструкцій, що мають мало спільного з реальністю. Прикладній економіці взагалі відмовляють у праві усвідом- 
лення суті об’єкта. Головна їі місія вбачається у застосуванні наукових економічних знань для вирішення практичних завдань. Теорія сприймається не інакше як інструмент. За М. Фрідменом, вона потрібна не для того, щоб отримати «фотографічне відтворення» світу, а для того, щоб «аналізувати» його за допомогою «фрундаментальної та відносно простої структури» [2]. Таким чином, сучасний критичний (трансцендентальний) реалізм бачить завдання науки, у тому числі економічної, у виявленні та дослідженні структур і механізмів, що лежать в основі подій досвіду, за допомогою інструментарію абдукції [5].

У сучасних взаємодіях і взаємопроникненні різних видів наукового і позанаукового знання, у тому числі економічного в контексті аграрного виробництва, істина зовсім не вмирає, а дорослішае та ускладняеться, постає як «вільний синтез», покликаний «розкрити всеохоплюючий сенс буття в істині» (К. Ясперс) у контексті взаємного порівняння і діалогу різних ідей, теорій та форм знання, пов'язаних 3 ними практик i соціальних реальностей [3]. Наукова складова цілісної істини є складною системою співвідношень, з одного боку, відношення наукового економічного знання до об'єкта, і з іншого - відношень знання до суб'єкта, умов, процесу, результату та наукової та практичної економічної діяльності, а також відношень економічного знання до самого себе.

Виділення економіки аграрного сектора як об'єкта пізнання лише 3 погляду може здатися простим завданням. Поняття економіки, виникло лише після того, як сама економіка як об'єктивне явище виділилася 3 нероздільної насамперед соціальної тканини в автономну підсистему суспільства, що й відбулося в процесі формування ринкових економік вже в Новий час. Варто зауважити, що етимологічний попередник сучасної «економіки» давньогрецьке слово «ойкономія» було набагато ширшим за значенням і охоплювало все, що належало до ведення домашнього господарства - від агротехніки до побутової гігієни та сімейних відносин.

Першим із великих економістів, хто виявив усвідомлений інтерес до картин економічної реальності, або онтології, як особливого типу знання, був, мабуть, Шумпетер. У своїй «Історії економічного аналізу» він зазначив: «Щоб мати можливість сорормулювати будь-яку проблему, насамперед ми повинні мати перед собою образ деякої взаємопов'язаної сукупності явищ як заслуговуючої уваги на об'єкт наших аналітичних зусиль... Такого роду бачення не тільки історично має передувати початку дослідження в будьякій галузі, але може і наново вторгатися в історію кожної сфрормованої науки щоразу, коли з'являеться людина, здатна бачити речі в такому світлі, джерело якого не може бути знайдено серед фракторів, методів і результатів, що характеризують раніше досягнутий рівень розвитку науки» [7]. Систематична робота 3 виявлення та аналізу економічних онтологій почалася пізніше і була пов'язана 3 переосмисленням історії економічної науки на базі методологічних ідей I. Лакатоша [5]. Ідентифікація та зіставлення конкуруючих науково-дослідних програм перед- бачало передусім виявлення їхньої онтологічної компоненти, або, у термінах Лакатоша, «жорсткого ядра». Це дозволило сорормувати нове, більш ємне уявлення про логіку розвитку економічної науки, показати, що структура економічного знання, з погляду його змісту, формувалася головним чином шляхом розширення спектра науково-дослідних програм і наукових напрямів, шкіл і традицій, що склалися на їх основі [5].

3 позищій кореспондентської концепції наукової істини претензії на останню в трьох верхніх ешелонах економічного знання багато в чому знімаються, бо наукове знання тут потрапляе у простір позанаукового і втрачає необхідну частину своєї ідентичності. 3 позицій концепції цілісної (загальної) істини саме на цих рівнях відбуваються зіткнення і взаємодія видимих, поверхових форм наукових і позанаукових елементів цілісної істини. Але щоб ця видима частина останньої була адекватно ідентифікована, необхідна усестороння діагностика їі невидимої частини. Елементи наукової істини, що знаходяться на двох нижніх рівнях економічного знання, повинні бути синтезовані 3 відповідними елементами істинності позанаукового знання. Більше того, велика складна система агарного сектору не може бути на одному рівні тільки економічною, а на іншому - тільки соціальною або політичною. Взаємодія економічної, екологічної, соціальної, духовної та політичної сорер формує їі на всіх рівнях, як невід'ємне середовище всіх рівнів наукового пізнання. Отже, достатньо ймовірним $є$ наявність позанаукових i наукових елементів цілісної істини на всіх рівнях економічного знання аграрного сектора, і сама вона в такому випадку є результатом і синергією синтезу зазначених елементів. Таким чином, у вчених-економістів є одна місія - пошук цілісної істини.

Висновки. Вважаємо за необхідне відмітити, що у сучасній економічній науці разом 3 ускладненням наукової істини i процесу їі набуття набувається розуміння неможливості останнього поза зверненням до цілісної істини та іiі пізнанням. Досягнутий рівень розвитку економічної науки аграрного сектору та економічного знання не дозволяе досягти цілісної істини. Однак навіть принципова нездоланність й неможливість не є підставою для відхилення самої ідеї економічно-універсального знання та його істинності. Адже неможливість абсолютної істини в науці не спростовуе інтереси вчених-економістів, які шукають відносну наукову істину економіки аграрного сектору задля виявлення подальших перспектив та векторів істинно-раціонального фоунціонування галузі. Науковцям економічного пошуку в аграрному секторі варто скористатися досвідом науки і навчитися визначати міру і відносність цілісної істини, жорсткі умови, передумови і межі, в яких економіко-універсальне знання відповідає тій чи іншій сфрері надскладного об'екта. Також вважаємо за необхідне зазначити, що економічна наука потребуе профресіоналізації методології, що започаткуе істотні зміни у взаємовідносинах між методологами і фрахівцями у агарному секторі та забезпечить істину наукових пізнань на рівні стратегічних дій. 


\section{Список літератури:}

1. Ананьин О.И. Структура экономико-теоретического знания: методологический анализ. Москва : Наука, 2005. С. $120-150$.

2. Антоновский А.Ю. Наука как общественная подсистема. Никлас Луман о механизмах социальной эволюции знания и истины. Вопросы фбилософбии. 2017. № 7. С. 154-167.

3. Блауг М. Методология экономической науки, или как экономисты объясняют. Bопросы экономики. 2004. C. $121-151$.

4. Лебедев С.А. Пересборка эпистемологического. Вопросы фбилософбии. 2015. № 6. С. 53-64.

5. Лоусон Т. Современная «экономическая теория» в свете реализма. Вопросы эконолики. 2006. № 2. С. $75-98$.

6. Тарасевич В.Н. Постнеклассический вызов фундаментальной экономической науке. Вопросы эконолики. 2004. № 4. C. 107-117.

7. Шлиссер Э. Экономическая теория и эксперимент: Исаак Ньютон, Милтон Фридмен и Вернон Смит. 2007. № 3. C. 55-70.

8. Экономика как искусство: методологические вопросы применения экономической теории в прикладных социально-экономических исследованиях. Москва : Наука, 2008. 255 с.

\section{References:}

1. Ananyn O.Y. (2005) Struktura əkonomyko-teoretycheskoho znanyia: metodolohycheskyi analyz [The structure of economic-theoretical knowledge: methodological analysis]. Moscow: Nauka.

2. Antonovskyi A.Yu. (2017) Nauka kak obshchestvennaia podsystema. Nyklas Luman o mekhanyzmakh sotsyalnoi evoliutsyy znanyia y ystyn [Science as a social subsystem. Niklas Luhmann on the mechanisms of social evolution of knowledge and truth]. Voprosi fylosofyy, no. 7, pp. 154-167.

3. Blaugh M. (2004) Metodologhyja ekonomycheskoj nauky, yly kak ekonomysty objasnjajut [Methodology of economic science, or as economists explain]. Voprosi ekonomyky, pp. 121-151.

4. Lebedev S.A. (2015) Peresborka epystemologhycheskogho [Reassembly of the epistemological]. Voprosi fylosofyy, no. 6 , pp. 53-64

5. Louson T. (2006) Sovremennaja ekonomycheskaja teoryja v svete realyzma [Modern "economic theory" in the light of realism]. Voprosi ekonomyky, no. 2, pp. 75-98.

6. Tarasevych V.N. (2004) Postneklassycheskyj vyzov fundamentaljnoj ekonomycheskoj nauke [Post-nonclassical challenge of fundamental economic science]. Voprosi ekonomyky, no. 4, pp. 107-117.

7. Shlysser E. (2007) Ekonomycheskaja teoryja y eksperyment: Ysaak Njjuton, Mylton Frydmen y Vernon Smyt. [Economic theory and experiment: Isaac Newton, Milton Friedman and Vernon Smith], no. 3, pp. 55-70.

8. Ekonomyka kak yskusstvo: metodologhycheskye voprosi prymenenyja ekonomycheskoj teoryy $\mathrm{v}$ prykladnikh socyaljno-ekonomycheskykh yssledovanyjakh (2008) [Economics as an art: methodological issues of the application of economic theory in applied socio-economic research]. Moscow: Nauka. 